\title{
Diastereoselective $\left[\mathrm{Cu}(\mathrm{MeCN})_{4} \mathrm{BF}_{4} / \mathrm{BF}_{3} \cdot \mathrm{Et}_{2} \mathrm{O}\right]$-Catalyzed Cyclopro- penation of Alkynes: Asymmetric Synthesis of $\beta$-Amino- $\alpha$-cyclo- propenyl Phosphonates
}

\author{
Haihong Ge ${ }^{a}$ \\ Shuang Liu ${ }^{a}$ \\ Yan Cai ${ }^{\mathrm{a}}$ \\ Zenghui Gao ${ }^{a}$ \\ Siyi Dua \\ Zhiwei Miao*a,b (D) \\ Guixian Xie*c \\ a State Key Laboratory of Elemento-Organic Chemistry, Insti- \\ tute of Elemento-Organic Chemistry, College of Chemistry, \\ Nankai University, Tianjin 300071, P. R. of China \\ miaozhiwei@nankai.edu.cn \\ b Collaborative Innovation Center of Chemical Science and Engi- \\ neering (Tianjin), Tianjin 300071, P. R. of China \\ ' College of Resources and Environment, Hunan Agricultural \\ University, Changsha 410128, P. R. of China \\ xieguixian@126.com
}

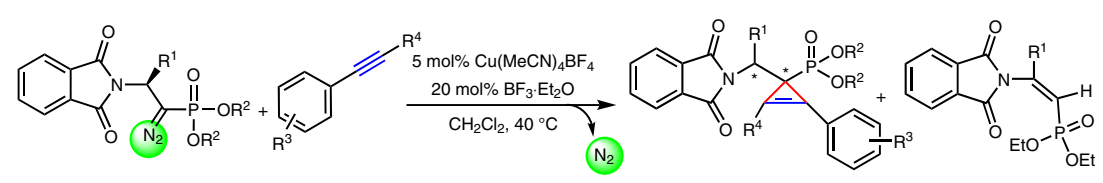

Received: 31.05.2017

Accepted after revision: 06.07.2017

Published online: 03.08 .2017

DOI: 10.1055/s-0036-1590969; Art ID: so-2017-d0020-op

License terms: cc)

Abstract The diastereospecific formation of $\beta$-amino- $\alpha$-cyclopropenyl phosphonates has been achieved in moderate yields from the cyclopropenation of 1 -alkynes with dialkyl $\alpha$-diazophosphonates. The reaction was performed by using a combined catalyst consisting of $\mathrm{Cu}(\mathrm{MeCN})_{4} \mathrm{BF}_{4}$ and $\mathrm{BF}_{3} \cdot \mathrm{Et}_{2} \mathrm{O}$ as additive in dichloromethane at $40{ }^{\circ} \mathrm{C}$. $\mathrm{A}$ possible mechanism for the reaction has been proposed to explain the origin of the activation and the asymmetric induction. This method provides a versatile approach to $\beta$-amino- $\alpha$-cyclopropenylphosphonates containing a quaternary stereogenic center with good efficiency and diastereoselectivity.

Key words cyclopropenation, $\alpha$-diazophosphonates, asymmetric synthesis, cyclopropenylphosphonates, $\mathrm{Cu}(\mathrm{MeCN})_{4} \mathrm{BF}_{4} / \mathrm{BF}_{3} \cdot \mathrm{Et}_{2} \mathrm{O}$

Cyclopropenes are a unique class of the smallest ring compound with a double bond, and the combination of high strain and unsaturation renders cyclopropenes as versatile synthons in a wide variety of organic synthesis. ${ }^{1}$ To enhance the synthetic potential of cyclopropenes further, the development of expeditious methods for their synthesis is highly desirable. ${ }^{2}$ One of the most efficient catalytic asymmetric methods for their preparation involves the reaction of alkynes with diazo compounds using chiral copper(I), ${ }^{3}$ iridium(II), ${ }^{4}$ cobalt(II), ${ }^{5}$ or rhodium(II $)^{6}$ catalysts. Diazo compounds are commonly used in formation of metallocarbenoids, which can subsequently undergo diverse chemical transformations. ${ }^{7}$ In 1992, Doyle, Müller and coworkers reported the first cyclopropenation reactions of diazoacetates with terminal alkynes using $\left[\mathrm{Rh}_{2}(5 S \text {-mepy })_{4}\right]$ as a chiral catalyst. ${ }^{8}$ Corey and co-workers also reported a sig- nificantly improved enantioselective cyclopropenation of ethyl diazoacetate with 1-alkynes using a new rhodium complex, $\mathrm{Rh}_{2}(\mathrm{OAc})(\mathrm{DPTI})_{3}$, as a catalyst. ${ }^{9}$ Although high levels of enantioselectivity (up to $99 \%$ ee) in cyclopropenations of terminal alkynes with aryldiazoacetates under catalysis by $\left[\mathrm{Rh}_{2}(\mathrm{~S} \text {-dosp })_{4}\right]$ have been reported by Davies and coworkers, ${ }^{10}$ stereoselective syntheses of the corresponding cyclopropenylphosphonates using such a strategy remain scarce. ${ }^{11}$

$\alpha$-Diazophosphonates are phosphorus analogues of $\alpha$ diazoacetates, and therefore could undergo a range of chemical transformations and the synthesis of varieties of functionalized phosphorous compounds. ${ }^{12}$ In 2013, Charette and co-workers reported the first catalytic asymmetric synthesis of bis-acceptor cyclopropylphosphonates through the reaction of $\alpha$-cyano diazophosphonates with allenes catalyzed by $\mathrm{Rh}_{2}(S \text {-IBAZ })_{4}$ under mild reaction conditions. ${ }^{13}$ Cyclopropylphosphonates demonstrate a range of biological and biochemical properties. ${ }^{14}$ By analogy with cyclopropylphosphonates, ${ }^{15}$ the development of efficient methods for the preparation of cyclopropenephosphonates is attracting increasing attention. In particular, the presence of a quaternary stereocenter in a highly substituted cyclopropenephosphonate can lead to interaction with certain proteases and a resistance to proteolytic degradation. ${ }^{14}$

Recently, we reported novel $\alpha$-diazophosphonyl compounds prepared from natural amino acids that be used to could perform combined $\mathrm{C}-\mathrm{H}$ functionalization and $\mathrm{O}-\mathrm{H}$ insertion to form tertiary $\beta$-alkoxy-substituted $\beta$-aminophosphonates (Scheme 1, Eq. 1). ${ }^{16}$ As a natural extension of the combined $\mathrm{C}-\mathrm{H}$ functionalization/O-H insertion reaction, we have developed a regioselective boron trifluoridecatalyzed $\mathrm{C}-\mathrm{H}$ functionalization/S-H insertion reaction for 

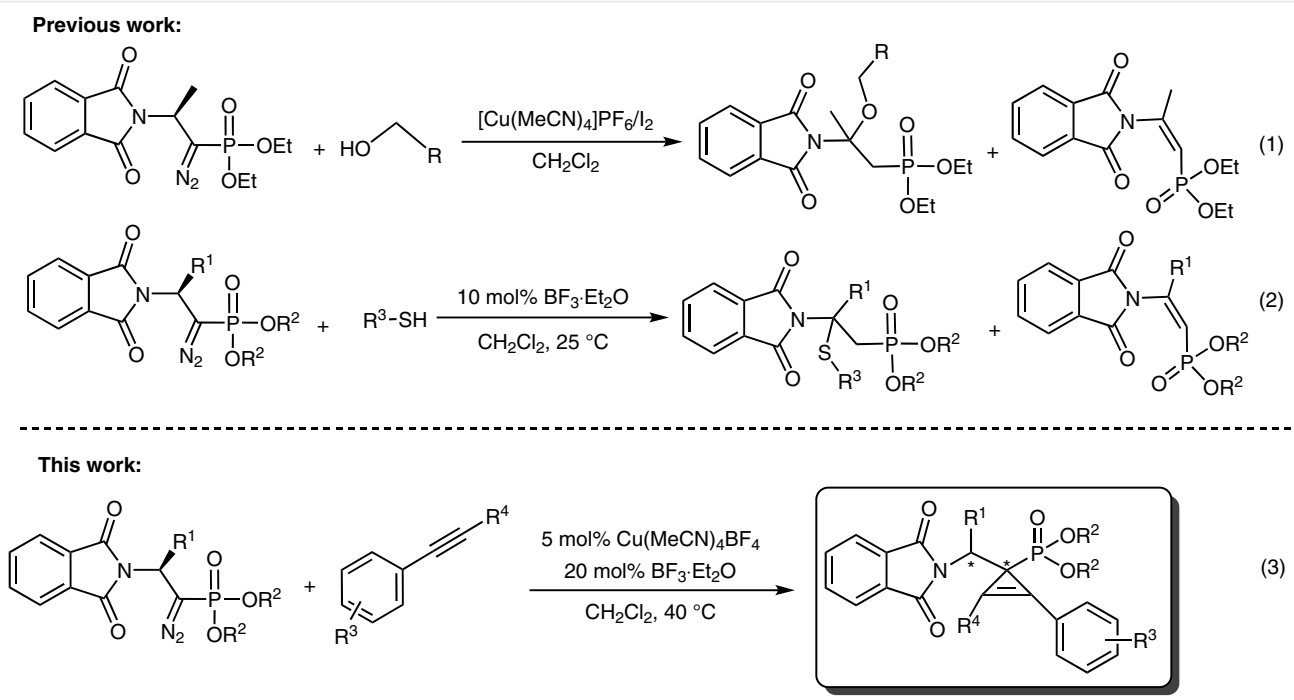

Scheme 1 Previous and proposed work

the synthesis of $N, S$-acetals containing quaternary centers (Scheme 1, Eq. 2). ${ }^{17}$ In a continuation of our interest in the chemistry of aminophosphorus derivatives, ${ }^{18}$ we herein report the first example of the conversion of dialkyl $\alpha$-diazophosphonates into cyclopropenylphosphonate derivatives catalyzed by tetrakis (acetonitrile)copper(I) tetrafluoroborate/boron trifluoride $\left[\mathrm{Cu}(\mathrm{MeCN})_{4} \mathrm{BF}_{4} / \mathrm{BF}_{3} \cdot \mathrm{Et}_{2} \mathrm{O}\right]$ in a highly diastereoselective manner (Scheme 1, Eq. 3).

We began our investigations by studying the reaction of diethyl $\alpha$-diazophosphonate $\mathbf{1} \mathbf{a}^{16}$ with phenylacetylene $\mathbf{2 a}$ in the presence of catalyst in dichloromethane at $25^{\circ} \mathrm{C}$ (Table 1$)$. The results revealed that transition-metal catalysts such as $\mathrm{Rh}_{2}(\mathrm{OAc})_{4}$ and $\mathrm{Hg}(\mathrm{OTf})_{2}$ did not decompose $\mathbf{1 a}$ in the presence of 2a (entries 1 and 2). The other catalysts tested (e.g., CuOTf, AgOTf, and $\mathrm{Cu}(\mathrm{MeCN})_{4} \mathrm{PF}_{6}$ ) could be used to promote the reaction, resulting in low yields of product with moderate diastereoselectivities (entries 3-5). To our delight $\mathrm{Cu}(\mathrm{MeCN})_{4} \mathrm{BF}_{4}$ catalyzed the decomposition of $\mathbf{1 a}$, and diethyl(2-(phenyl-cycloprop-2-enyl)-2-(1,3-dioxoisoindolin-2-yl)ethyl)phosphonate (3a) was obtained with good diastereoselectivity $(d r=12: 1)$ in $29 \%$ yield (entry 6 ). In addition, a 1,2-hydrogen migration by-product ( $Z$ )-diethyl(2-(1,3-dioxoisoindolin-2-yl)prop-1-en-1-yl) phosphonate (4a) was obtained in $9 \%$ yield. The molecular structure of 3a was determined based on ${ }^{1} \mathrm{H},{ }^{31} \mathrm{P},{ }^{13} \mathrm{C}$ NMR, and 2D NMR spectroscopy and mass spectrometry. ${ }^{19}$ This result encouraged us to choose $\mathrm{Cu}(\mathrm{MeCN})_{4} \mathrm{BF}_{4}$ as the catalyst for further optimization of the reaction conditions. To improve the reactivity and diastereoselectivity, the effects of different additives and solvents were investigated.

Initially, additives were evaluated to study the diastereoselectivity of this transformation. As shown in Table 1, both the diastereoselectivity and the ratio of the two products $\mathbf{3 a}$ and $\mathbf{4 a}$ was affected dramatically by the additive. In the presence of $\mathrm{Cu}(\mathrm{MeCN})_{4} \mathrm{BF}_{4}$ as the catalyst (5 mol\%) and
$\mathrm{BF}_{3} \cdot \mathrm{Et}_{2} \mathrm{O}(20 \mathrm{~mol} \%)$ as the additive in dichloromethane, the reaction proceeded with an increased combined yield and good diastereoselectivity $(d r=12: 1)$ (entry 7$)$. Furthermore, we found that high temperatures favored this reaction. When the reaction was carried out at $40^{\circ} \mathrm{C}$, the desired product 3a could be obtained in $66 \%$ yield (entry 8 ). After screening $\mathrm{BF}_{3} \cdot \mathrm{Et}_{2} \mathrm{O}$, it was found that acetone, $\mathrm{CH}_{3} \mathrm{CN}$, DMF, and iodine did not give superior results in terms of either reactivity or stereoselectivity (entries 9-12).

With the optimum combination of $\mathrm{Cu}(\mathrm{MeCN})_{4} \mathrm{BF}_{4}$ catalyst and $\mathrm{BF}_{3} \cdot \mathrm{Et}_{2} \mathrm{O}$ additive, we next carried out the reaction in different solvents to determine the best solvent for this reaction. Toluene, THF, DME, and 1,2-dichloroethane all provided lower yields of the desired products $\mathbf{3 a}$ and $\mathbf{4 a}$ with moderate diastereoselectivities (Table 1 , entries 1316). This screening therefore identified $\mathrm{CH}_{2} \mathrm{Cl}_{2}$ as the optimal solvent for this reaction. Furthermore, a decrease in the catalyst loading to $2 \mathrm{~mol} \% \mathrm{Cu}(\mathrm{MeCN})_{4} \mathrm{BF}_{4}$ and $10 \mathrm{~mol} \%$ $\mathrm{BF}_{3} \cdot \mathrm{Et}_{2} \mathrm{O}$ led to a decrease in both yield and diastereoselectivity (entry 17). A similar result was obtained when the reaction was performed in $\mathrm{CH}_{2} \mathrm{Cl}_{2}$ with increased catalyst loading to $10 \mathrm{~mol} \% \mathrm{Cu}(\mathrm{MeCN})_{4} \mathrm{BF}_{4}$ and $30 \mathrm{~mol} \% \mathrm{BF}_{3} \cdot \mathrm{Et}_{2} \mathrm{O}$ (entry 18). Thus, the optimal reaction conditions for this transformation were determined to be $0.28 \mathrm{mmol} \alpha$-diazo phosphonate 1a, 5.0 equivalents of phenylacetylene $\mathbf{2 a}, 5$ $\mathrm{mol} \% \mathrm{Cu}(\mathrm{MeCN})_{4} \mathrm{BF}_{4}$ and $20 \mathrm{~mol} \% \mathrm{BF}_{3} \cdot \mathrm{Et}_{2} \mathrm{O}$ as co-catalyst in $6 \mathrm{~mL} \mathrm{CH}_{2} \mathrm{Cl}_{2}$ as solvent at $40^{\circ} \mathrm{C}$.

Under the optimal reaction conditions, the substrate scope of this reaction was investigated (Table 2). The impact of different groups on the $\beta$-position of dialkyl $\alpha$-diazophosphonates 1 was evaluated. $\alpha$-Diazophosphonates 1a-e with different substituents in the $\beta$-position, such as meth$\mathrm{yl}$, benzyl, isobutyl, ethyl, and 4-acetoxybenzyl groups, afforded moderate yields of the $\beta$-amino- $\alpha$-cyclopropenylphosphonates $\mathbf{3 a}$-e and the 1,2-hydride migration products 
Table 1 Optimization of the Reaction Conditions ${ }^{\mathrm{a}}$

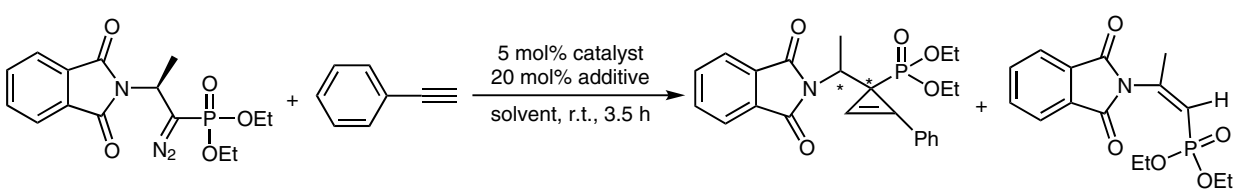

1a

2a

3a

$4 a$

\begin{tabular}{|c|c|c|c|c|c|c|c|}
\hline Entry & Catalysts & Additive & Solvent & $(3 a: 4 a)$ ratio $^{b}$ & Overall yield $(\%)^{c}$ & Yield 3a (\%) & $d r^{\mathrm{e}}$ \\
\hline 1 & $\mathrm{Rh}_{2}(\mathrm{OAc})_{4}$ & - & $\mathrm{CH}_{2} \mathrm{Cl}_{2}$ & - & N.R. & N.R. & - \\
\hline 2 & $\mathrm{Hg}(\mathrm{OTf})_{2}$ & - & $\mathrm{CH}_{2} \mathrm{Cl}_{2}$ & - & N.R. & N.R. & - \\
\hline 3 & CuOTf & - & $\mathrm{CH}_{2} \mathrm{Cl}_{2}$ & $63: 37$ & $<10$ & $<10$ & $8: 1$ \\
\hline 4 & AgOTf & - & $\mathrm{CH}_{2} \mathrm{Cl}_{2}$ & $57: 43$ & $<10$ & $<10$ & $10: 1$ \\
\hline 5 & $\mathrm{Cu}(\mathrm{MeCN})_{4} \mathrm{PF}_{6}$ & - & $\mathrm{CH}_{2} \mathrm{Cl}_{2}$ & $60: 40$ & 23 & 14 & $12: 1$ \\
\hline 6 & $\mathrm{Cu}(\mathrm{MeCN})_{4} \mathrm{BF}_{4}$ & - & $\mathrm{CH}_{2} \mathrm{Cl}_{2}$ & $77: 23$ & 38 & 29 & $12: 1$ \\
\hline 7 & $\mathrm{Cu}(\mathrm{MeCN})_{4} \mathrm{BF}_{4}$ & $\mathrm{BF}_{3} \cdot \mathrm{Et}_{2} \mathrm{O}$ & $\mathrm{CH}_{2} \mathrm{Cl}_{2}$ & $78: 22$ & 42 & 33 & $12: 1$ \\
\hline $8^{f}$ & $\mathrm{Cu}(\mathrm{MeCN})_{4} \mathrm{BF}_{4}$ & $\mathrm{BF}_{3} \cdot \mathrm{Et}_{2} \mathrm{O}$ & $\mathrm{CH}_{2} \mathrm{Cl}_{2}$ & $82: 18$ & 81 & 66 & $12: 1$ \\
\hline 9 & $\mathrm{Cu}(\mathrm{MeCN})_{4} \mathrm{BF}_{4}$ & $\mathrm{CH}_{3} \mathrm{COCH}_{3}$ & $\mathrm{CH}_{2} \mathrm{Cl}_{2}$ & $75: 25$ & 28 & 21 & $10: 1$ \\
\hline 10 & $\mathrm{Cu}(\mathrm{MeCN})_{4} \mathrm{BF}_{4}$ & $\mathrm{CH}_{3} \mathrm{CN}$ & $\mathrm{CH}_{2} \mathrm{Cl}_{2}$ & $70: 30$ & 33 & 23 & $>25: 1$ \\
\hline 11 & $\mathrm{Cu}(\mathrm{MeCN})_{4} \mathrm{BF}_{4}$ & DMF & $\mathrm{CH}_{2} \mathrm{Cl}_{2}$ & $78: 22$ & 25 & 20 & $15: 1$ \\
\hline 12 & $\mathrm{Cu}(\mathrm{MeCN})_{4} \mathrm{BF}_{4}$ & iodine & $\mathrm{CH}_{2} \mathrm{Cl}_{2}$ & $64: 36$ & 40 & 26 & $13: 1$ \\
\hline $13^{f}$ & $\mathrm{Cu}(\mathrm{MeCN})_{4} \mathrm{BF}_{4}$ & $\mathrm{BF}_{3} \cdot \mathrm{Et}_{2} \mathrm{O}$ & toluene & $76: 24$ & 38 & 29 & $16: 1$ \\
\hline $14^{f}$ & $\mathrm{Cu}(\mathrm{MeCN})_{4} \mathrm{BF}_{4}$ & $\mathrm{BF}_{3} \cdot \mathrm{Et}_{2} \mathrm{O}$ & THF & $80: 20$ & 47 & 38 & $15: 1$ \\
\hline $15^{f}$ & $\mathrm{Cu}(\mathrm{MeCN})_{4} \mathrm{BF}_{4}$ & $\mathrm{BF}_{3} \cdot \mathrm{Et}_{2} \mathrm{O}$ & $\mathrm{DME}^{\mathrm{g}}$ & $78: 22$ & 42 & 33 & $10: 1$ \\
\hline $16^{f}$ & $\mathrm{Cu}(\mathrm{MeCN})_{4} \mathrm{BF}_{4}$ & $\mathrm{BF}_{3} \cdot \mathrm{Et}_{2} \mathrm{O}$ & 1,2-dichloroethane & $82: 18$ & 42 & 34 & $12: 1$ \\
\hline $17^{\mathrm{f}, \mathrm{h}}$ & $\mathrm{Cu}(\mathrm{MeCN})_{4} \mathrm{BF}_{4}$ & $\mathrm{BF}_{3} \cdot \mathrm{Et}_{2} \mathrm{O}$ & $\mathrm{CH}_{2} \mathrm{Cl}_{2}$ & $68: 32$ & 44 & 30 & $8: 1$ \\
\hline $18^{\mathrm{f}, \mathrm{i}}$ & $\mathrm{Cu}(\mathrm{MeCN})_{4} \mathrm{BF}_{4}$ & $\mathrm{BF}_{3} \cdot \mathrm{Et}_{2} \mathrm{O}$ & $\mathrm{CH}_{2} \mathrm{Cl}_{2}$ & $66: 34$ & 51 & 34 & $10: 1$ \\
\hline
\end{tabular}

a Unless otherwise specified, all reactions were carried out using $\alpha$-diazophosphonate $\mathbf{1 a}(0.28 \mathrm{mmol}, 1$ equiv) and phenylacetylene $\mathbf{2 a}$ ( 1.40 mmol, 5 equiv) in the specified solvent $\left(6 \mathrm{~mL}\right.$ ) with 5 mol\% catalyst and 20 mol\% additive at $25^{\circ} \mathrm{C}$ for $3.5 \mathrm{~h}$ (addition over $1.5 \mathrm{~h}$, then a further $2 \mathrm{~h}$ ).

$\mathrm{b}$ The product ratio was determined by ${ }^{31} \mathrm{P}$ NMR spectroscopic analysis of the crude product.

c Overall yield of the mixture of $\mathbf{3 a}$ and $\mathbf{4 a}$ after silica gel chromatograph.

${ }^{\mathrm{d}}$ Yield of isolated product.

e Diastereomeric ratio $(d r)$ based on ${ }^{31} \mathrm{P}$ NMR spectroscopic analysis of the isolated product $3 a$.

${ }^{f}$ Reaction temperature $40^{\circ} \mathrm{C}$.

$9 \mathrm{DME}=$ dimethoxyethane.

h 2 mol\% $\mathrm{Cu}(\mathrm{MeCN})_{4} \mathrm{BF}_{4}$ and $10 \mathrm{~mol} \% \mathrm{BF}_{3} \cdot \mathrm{Et}_{2} \mathrm{O}$ were used.

i $10 \mathrm{~mol} \% \mathrm{Cu}(\mathrm{MeCN})_{4} \mathrm{BF}_{4}$ and $30 \mathrm{~mol}_{\%} \mathrm{BF}_{3} \cdot \mathrm{Et}_{2} \mathrm{O}$ were used.

4a-e (entries 1-5). It is worth noting that diethyl $\alpha$-diazophosphonate 1f, derived from methionine, did not undergo reaction to give the desired products, probably due to the fact that the sulfur atom coordinates with the copper(I) and hinders the reaction (entry 6). Instead, the starting material 1f decomposed under the reaction conditions. In addition to phenylacetylene, 3-methylphenyl acetylene and 4-methylphenylacetylene were also examined in the cyclopropenation reaction with carbenoids derived from dialkyl $\alpha$-diazophosphonates $\mathbf{1 b}$ and $\mathbf{1 g}$. Electron-rich phenylacetylene derivatives, substituted either at the meta-, or para-position, all provided good yields and diastereoselectivities of the corresponding $\beta$-amino- $\alpha$-cyclopropenylphosphonates (entries 7 and 8). Chiral cyclopropene derivatives $\mathbf{3 i}$ and $\mathbf{3 j}$ from reactions of aromatic alkynes containing both electron-withdrawing and -donating groups at the para-posi- tion could also be obtained in poor yields but with good diastereoselectivities (entries 9 and 10). The cyclopropenation could also be conducted on the internal alkyne prop-1ynyl-benzene $\mathbf{2 f}$ with excellent diastereoselectivity (>30:1), albeit in diminished yield (11\%), presumably due to the steric effect (entry 11).

To assess the effects of the substrate on product selectivity, we set out to study the reactions of a series of dialkyl $\alpha$-diazophosphonates $\mathbf{1 h}-\mathbf{l}$ under $\mathrm{Cu}(\mathrm{MeCN})_{4} \mathrm{BF}_{4} / \mathrm{BF}_{3} \cdot \mathrm{Et}_{2} \mathrm{O}$ catalysis. When the steric bulk of the $\mathrm{R}^{2}$ group was increased from methyl to isopropyl or $n$-butyl, similar yields were obtained. These results showed that the size of the $\mathrm{R}^{2}$ group on the $\alpha$-diazophosphonates $\mathbf{1}$ has almost no influence on reactivity in this cyclopropenation reaction (Table 2 , entries 12-16). The method was successful for alkynes that are conjugated to an arene. However, cyclopropene 
Table 2 Scope of the Reaction ${ }^{\mathrm{a}}$

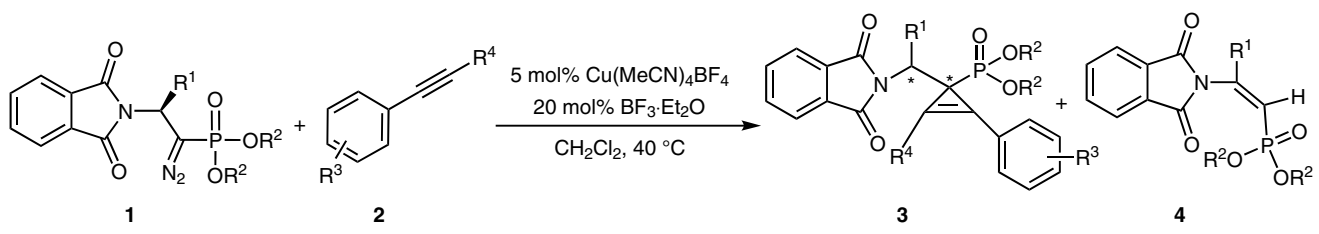

\begin{tabular}{|c|c|c|c|c|c|c|c|c|c|}
\hline Entry & Product & $\mathrm{R}^{1}$ & $\mathrm{R}^{2}$ & $\mathrm{R}^{3}$ & $\mathrm{R}^{4}$ & 3/4 Ratio ${ }^{b}$ & Overall yield (\%) & Yield 3 (\%) & $d r^{e}$ \\
\hline 1 & $3 a$ & $\mathrm{CH}_{3}(\mathbf{1} \mathbf{a})$ & $\mathrm{CH}_{2} \mathrm{CH}_{3}$ & $\mathrm{H}(\mathbf{2 a})$ & $\mathrm{H}$ & $82: 18$ & 81 & 66 & $12: 1$ \\
\hline 2 & $3 b$ & $\mathrm{CH}_{2} \mathrm{C}_{6} \mathrm{H}_{5}(\mathbf{1} \mathbf{b})$ & $\mathrm{CH}_{2} \mathrm{CH}_{3}$ & $\mathrm{H}(\mathbf{2 a})$ & $\mathrm{H}$ & $78: 22$ & 74 & 58 & $>30: 1$ \\
\hline 3 & $3 c$ & $\mathrm{CH}_{2} \mathrm{CH}\left(\mathrm{CH}_{3}\right)_{2}(\mathbf{1 c})$ & $\mathrm{CH}_{2} \mathrm{CH}_{3}$ & $\mathrm{H}(\mathbf{2 a})$ & $\mathrm{H}$ & $83: 17$ & 67 & 56 & $16: 1$ \\
\hline 4 & $3 d$ & $\mathrm{CH}_{2} \mathrm{CH}_{3}(\mathbf{1 d})$ & $\mathrm{CH}_{2} \mathrm{CH}_{3}$ & $\mathrm{H}(\mathbf{2 a})$ & $\mathrm{H}$ & $81: 19$ & 74 & 60 & $8: 1$ \\
\hline 5 & $3 e$ & $p-\mathrm{AcOC}_{6} \mathrm{H}_{4}(\mathbf{1 e})$ & $\mathrm{CH}_{2} \mathrm{CH}_{3}$ & $\mathrm{H}(\mathbf{2 a})$ & H & $84: 16$ & 64 & 54 & $>30: 1$ \\
\hline 6 & $3 f$ & $\mathrm{CH}_{2} \mathrm{CH}_{2} \mathrm{SCH}_{3}(\mathbf{1 f})$ & $\mathrm{CH}_{2} \mathrm{CH}_{3}$ & $\mathrm{H}(\mathbf{2 a})$ & $\mathrm{H}$ & - & N.R. & - & - \\
\hline 7 & $3 g$ & $\mathrm{CH}_{2} \mathrm{C}_{6} \mathrm{H}_{5}(\mathbf{1 b})$ & $\mathrm{CH}_{2} \mathrm{CH}_{3}$ & $3-\mathrm{CH}_{3}(\mathbf{2 b})$ & $\mathrm{H}$ & $81: 19$ & 76 & 62 & $12: 1$ \\
\hline 8 & $3 \mathrm{~h}$ & $\mathrm{CH}_{2} \mathrm{C}_{6} \mathrm{H}_{5}(\mathbf{1 g})$ & $n-B u$ & $4-\mathrm{CH}_{3}(2 \mathrm{c})$ & $\mathrm{H}$ & $82: 18$ & 78 & 64 & $12: 1$ \\
\hline 9 & $3 \mathbf{i}$ & $\mathrm{CH}_{3}(\mathbf{1} \mathbf{a})$ & $\mathrm{CH}_{2} \mathrm{CH}_{3}$ & $4-F(\mathbf{2 d})$ & $\mathrm{H}$ & $61: 39$ & 31 & 19 & $30: 1$ \\
\hline 10 & $3 \mathbf{j}$ & $\mathrm{CH}_{2} \mathrm{C}_{6} \mathrm{H}_{5}(\mathbf{1 b})$ & $\mathrm{CH}_{2} \mathrm{CH}_{3}$ & 4-OMe (2e) & $\mathrm{H}$ & $45: 55$ & 55 & 25 & $31: 1$ \\
\hline 11 & $3 k$ & $\mathrm{CH}_{3}(\mathbf{1} \mathbf{a})$ & $\mathrm{CH}_{2} \mathrm{CH}_{3}$ & $H(\mathbf{2 f})$ & $\mathrm{CH}_{3}$ & $33: 67$ & 33 & 11 & $>30: 1$ \\
\hline 12 & 31 & $\mathrm{CH}_{3}(\mathbf{1 h})$ & $\mathrm{CH}_{3}$ & $\mathrm{H}(\mathbf{2 a})$ & $\mathrm{H}$ & $86: 14$ & 64 & 55 & $15: 1$ \\
\hline 13 & $3 m$ & $\mathrm{CH}_{2} \mathrm{C}_{6} \mathrm{H}_{5}(\mathbf{1 i})$ & $\mathrm{CH}_{3}$ & $\mathrm{H}(\mathbf{2 a})$ & $\mathrm{H}$ & $88: 12$ & 75 & 66 & $>30: 1$ \\
\hline 14 & $3 n$ & $\mathrm{CH}_{2} \mathrm{C}_{6} \mathrm{H}_{5}(\mathbf{1} \mathbf{j})$ & $i-\operatorname{Pr}$ & $\mathrm{H}(\mathbf{2 a})$ & $\mathrm{H}$ & $82: 18$ & 73 & 60 & $12: 1$ \\
\hline 15 & 30 & $\mathrm{CH}_{3}(\mathbf{1} \mathbf{k})$ & $n-B u$ & $\mathrm{H}(\mathbf{2 a})$ & $\mathrm{H}$ & $87: 13$ & 77 & 67 & $21: 1$ \\
\hline 16 & $3 p$ & $\mathrm{CH}_{2} \mathrm{C}_{6} \mathrm{H}_{5}(\mathbf{1} \mathbf{I})$ & $n-B u$ & $\mathrm{H}(\mathbf{2 a})$ & $\mathrm{H}$ & $82: 18$ & 73 & 60 & $>30: 1$ \\
\hline
\end{tabular}

a Reaction conditions: $\alpha$-diazophosphonate $1(0.28 \mathrm{mmol})$ and $\mathbf{2}\left(1.40 \mathrm{mmol}, 5\right.$ equiv) in $\mathrm{CH}_{2} \mathrm{Cl}_{2}(6 \mathrm{~mL})$ at $40{ }^{\circ} \mathrm{C}$ in the presence of $5 \mathrm{~mol} \% \mathrm{Cu}(\mathrm{MeCN})_{4} \mathrm{BF}{ }_{4}$ and 20 mol\% $\mathrm{BF}_{3} \cdot \mathrm{Et}_{2} \mathrm{O}$ for $3.5 \mathrm{~h}$ (addition over $1.5 \mathrm{~h}$, then a further $2 \mathrm{~h}$ ).

b The product ratio was based on ${ }^{31} \mathrm{P}$ NMR spectroscopic analysis of the crude product.

c Overall yield of the mixture of $\mathbf{3}$ and $\mathbf{4}$ after silica gel chromatography.

¿ Yield of isolated product.

e Diastereomeric ratio $(d r)$ based on ${ }^{31}$ P NMR spectroscopic analysis of the isolated product 3a.

products were not obtained when diethyl $\alpha$-diazophosphonate 1a was reacted with (triisopropyl)silylacetylene or 1hexyne.

A stepwise mechanism for the formation of the cyclopropenylphosphonates is outlined in Scheme 2. Firstly, $\alpha-$ diazophosphonate 1 releases $\mathrm{N}_{2}$ under the influence of the $\mathrm{Cu}$ catalyst on heating, affording $\mathrm{Cu}$-carbenoid $\mathrm{A}^{20}$ The role of the strong Lewis acids $\left(\mathrm{BF}_{3} \cdot \mathrm{Et}_{2} \mathrm{O}\right)$ could be to coordinate to the copper to give metallocarbenoid $\mathbf{B}$ in order to make the $\alpha$-diazo position more electron deficient. Carbenoid $\mathbf{B}$ is then trapped by the triple bond of ethynylbenzene to give vinyl cation $\mathbf{C}$. Subsequent cleavage of the $\mathrm{C}-\mathrm{Cu}$ bond of intermediate $\mathbf{C}$ with delivery of the electrons to the vinyl cation leads to cyclopropenyl phosphonate $\mathbf{3}$ with simultaneous regeneration of the $\mathrm{Cu}(\mathrm{I})$ catalyst and $\mathrm{BF}_{3} \cdot \mathrm{Et}_{2} \mathrm{O}$. Intermediate $\mathbf{B}$ may also be transformed into by-product $\mathbf{4}$ through loss of $\mathrm{Cu}(\mathrm{MeCN})_{4} \mathrm{BF}_{4}$ and $\mathrm{BF}_{3} \cdot \mathrm{Et}_{2} \mathrm{O}$ before the attack of phenylacetylene $\mathbf{2 a}$.

The diastereoselectivity observed in generating the cyclopropenyl phosphonates implies that conformational factors may play a role in the cyclopropenation process. In fact, the stereoselectivity can be attributed to steric hindrance between the phosphonate group and the $\mathrm{R}^{1}$ group, with attack occurring on the back face of the carbenoid preferentially. In forming intermediate $\mathbf{C}$, the terminal alkyne carbon is involved in $\mathrm{C}-\mathrm{C}$ bond formation with the carbenoid carbon, while positive charge build-up occurs at the internal sp-carbon. Furthermore, the second $\mathrm{C}-\mathrm{C}$ bond forms with inversion of the carbenoid center. This model is partly consistent with the observed sense of asymmetric induction, but there are a few anomalies. For instance, isopropyl phosphonate $\mathbf{1 j}$ leads to lower $d r$ than methyl phosphonate $\mathbf{1 i}$ (Table 2, entries 13 and 14).

In conclusion, we have developed a $\mathrm{Cu}(\mathrm{MeCN})_{4} \mathrm{BF}_{4} / \mathrm{BF}_{3} \cdot \mathrm{Et}_{2} \mathrm{O}$-catalyzed cyclopropenation of 1alkynes with dialkyl $\alpha$-diazophosphonates to synthesize $\beta$ amino- $\alpha$-cyclopropenyl phosphonates in moderate yields with good to excellent diastereoselectivities. The observed sense of asymmetric induction is rationalized by invoking steric hindrance between the phosphonate group and the $\mathrm{R}^{1}$ group of the $\alpha$-diazophosphonate. The present catalytic protocol provides attractive and easy access to $\beta$-amino- $\alpha$ - 
(n)

B

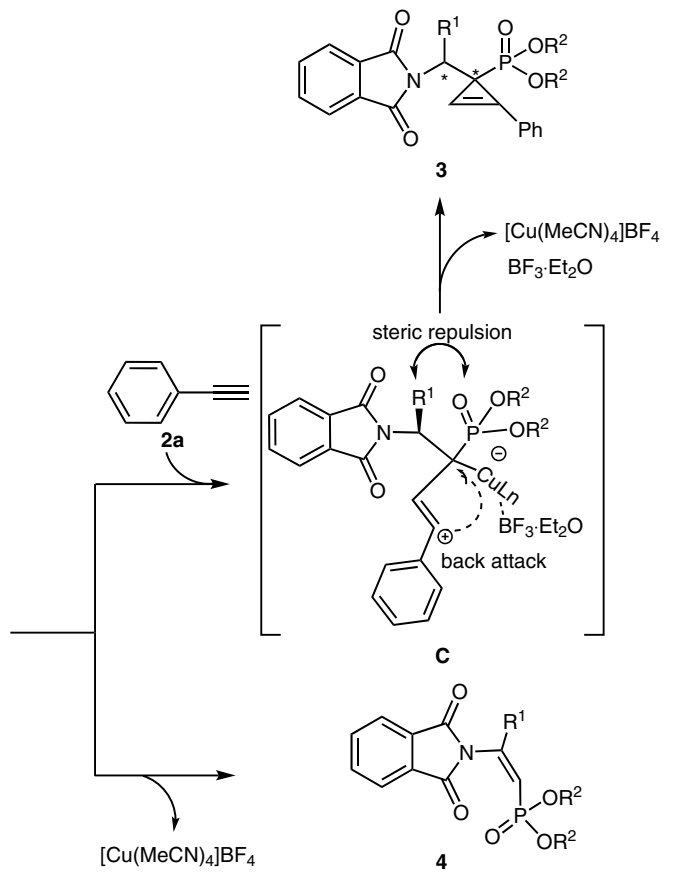

Scheme 2 Proposed reaction mechanism

cyclopropenyl phosphonates containing a quaternary stereogenic center. Further studies to explore the enantioselective synthesis of cyclopropenyl phosphonates are in progress in our laboratory.

All reactions and manipulations were performed using standard Schlenk techniques. Solvents were dried and distilled prior to use according to standard methods. Unless otherwise indicated, all materials were obtained from commercial sources, and used as purchased without dehydration. Flash column chromatography was performed on silica gel (particle size 10-40 $\mu \mathrm{m}$, Ocean Chemical Factory of Qingdao, China). Nitrogen gas (99.999\%) was purchased from Boc Gas Inc. ${ }^{1} \mathrm{H}$ NMR, ${ }^{13} \mathrm{C}$ NMR, and ${ }^{31} \mathrm{P}$ NMR spectra were recorded in $\mathrm{CDCl}_{3}$ with Bruker $400 \mathrm{MHz}$ spectrometers, TMS served as internal standard $(\delta=0 \mathrm{ppm})$ for ${ }^{1} \mathrm{H}$ NMR and ${ }^{13} \mathrm{C} \mathrm{NMR}, \mathrm{H}_{3} \mathrm{PO}_{4}$ served as internal standard $(\delta=0 \mathrm{ppm})$ for ${ }^{31} \mathrm{P}$ NMR. Mass spectra were recorded with a LCQ advantage spectrometer with ESI resource. HRMS were recorded with a PEXII and ZAB-HS spectrometer.

\section{Preparation of 3 and 4; General Procedure}

In an oven-dried Schlenk tube, $\left[\mathrm{Cu}(\mathrm{MeCN})_{4}\right] \mathrm{BF}_{4}(0.014 \mathrm{mmol})$ and $\mathrm{BF}_{3} \cdot \mathrm{Et}_{2} \mathrm{O}(0.056 \mathrm{mmol})$ were dissolved in freshly distilled $\mathrm{CH}_{2} \mathrm{Cl}_{2}(4$ $\mathrm{mL})$ under nitrogen, the requisite phenylacetylene $\mathbf{2}(1.4 \mathrm{mmol})$ was added and the solution was stirred for $30 \mathrm{~min}$ at $25^{\circ} \mathrm{C}$. $\alpha$-Diazophosphonate $\mathbf{1}(0.28 \mathrm{mmol})$ dissolved in $\mathrm{CH}_{2} \mathrm{Cl}_{2}(2 \mathrm{~mL})$ was then added to the reaction mixture dropwise over a period of $1.5 \mathrm{~h}$ by using a syringe pump. When the addition was complete, the reaction mixture was stirred for a further $2 \mathrm{~h}$ at $40{ }^{\circ} \mathrm{C}$. The solvent was then removed under reduced pressure and the crude residue was purified by silica gel chromatography, eluting with $\mathrm{CH}_{2} \mathrm{Cl}_{2} /$ EtOAc $(15: 1)$ to afford the corresponding products 3 and 4 .

Diethyl(1-(phenylcycloprop-2-enyl)-2-(1,3-dioxoisoindolin-2yl)ethyl)phosphonate (3a)

Yield: $0.085 \mathrm{~g}(66 \%)$; pale-yellow oil.

${ }^{1} \mathrm{H}$ NMR $\left(400 \mathrm{MHz}, \mathrm{CDCl}_{3}\right): \delta=7.61(\mathrm{dd}, J=5.2,3.2 \mathrm{~Hz}, 2 \mathrm{H}), 7.56(\mathrm{dd}$, $J=5.3,3.1 \mathrm{~Hz}, 2 \mathrm{H}), 7.49(\mathrm{~d}, J=7.1 \mathrm{~Hz}, 2 \mathrm{H}), 7.16-7.25(\mathrm{~m}, 3 \mathrm{H}), 7.01$ $(\mathrm{d}, J=4.1 \mathrm{~Hz}, 1 \mathrm{H}), 5.17-5.27(\mathrm{~m}, 1 \mathrm{H}, \mathrm{CH}), 4.11(\mathrm{dd}, J=12.8,5.7 \mathrm{~Hz}$, $4 \mathrm{H}), 1.70$ (d, $J=7.2 \mathrm{~Hz}, 3 \mathrm{H}), 1.30$ (td, $J=7.0,4.2 \mathrm{~Hz}, 6 \mathrm{H}$ ).

${ }^{13} \mathrm{C}$ NMR $\left(101 \mathrm{MHz}, \mathrm{CDCl}_{3}\right): \delta=168.35,133.57,131.51,129.77$, $129.59,128.30,125.48,122.71,116.00,97.61,62.02,61.88,47.44$ (d, $J=36.5 \mathrm{~Hz}), 30.15,28.17,16.16$.

${ }^{31} \mathrm{P} \operatorname{NMR}\left(162 \mathrm{MHz}, \mathrm{CDCl}_{3}\right): \delta=26.86$.

HRMS (ESI): $m / z[\mathrm{M}+\mathrm{H}]^{+}$calcd for $\mathrm{C}_{23} \mathrm{H}_{24} \mathrm{NO}_{5} \mathrm{P}: 426.1426$; found: 426.1470.

Diethyl(1-(phenylcycloprop-2-enyl)-2-(1,3-dioxoisoindolin-2-yl)2-phenylethyl)phosphonate (3b)

Yield: $0.086 \mathrm{~g}(58 \%)$; pale-yellow oil.

${ }^{1} \mathrm{H}$ NMR $\left(400 \mathrm{MHz}, \mathrm{CDCl}_{3}\right): \delta=7.49(\mathrm{~d}, J=6.5 \mathrm{~Hz}, 5 \mathrm{H}), 7.11-7.28(\mathrm{~m}$, $7 \mathrm{H}), 7.09(\mathrm{~d}, J=4.0 \mathrm{~Hz}, 2 \mathrm{H}), 5.43(\mathrm{~d}, J=11.0 \mathrm{~Hz}, 1 \mathrm{H}), 4.17(\mathrm{dd}$, $J=15.5,7.7 \mathrm{~Hz}, 4 \mathrm{H}), 3.06-3.83(\mathrm{~m}, 2 \mathrm{H}), 3.51(\mathrm{dd}, J=14.2,4.0 \mathrm{~Hz})$, $1.32-1.38(\mathrm{~m}, 6 \mathrm{H})$. 
${ }^{13} \mathrm{C}$ NMR $\left(101 \mathrm{MHz}, \mathrm{CDCl}_{3}\right): \delta=137.33,133.40,132.40,128.71$, $128.58,127.66,127.30,125.21,124.36,122.66,121.58,114.55,96.66$, $61.04,52.60$ (d, $J=45.4 \mathrm{~Hz}), 33.87,28.68,15.44$.

${ }^{31} \mathrm{P} \operatorname{NMR}\left(162 \mathrm{MHz}, \mathrm{CDCl}_{3}\right): \delta=26.57$.

HRMS (ESI): $m / z[\mathrm{M}+\mathrm{H}]^{+}$calcd for $\mathrm{C}_{29} \mathrm{H}_{28} \mathrm{NO}_{5} \mathrm{P}$ : 502.1739; found: 502.1783 .

\section{Diethyl(1-(phenylcycloprop-2-enyl)-2-(1,3-dioxoisoindolin-2-yl)- 3-methylbutyl)phosphonate (3c) \\ Yield: $0.078 \mathrm{~g}$ (56\%); pale-yellow oil.}

${ }^{1} \mathrm{H} \mathrm{NMR}\left(400 \mathrm{MHz}, \mathrm{CDCl}_{3}\right): \delta=7.50-7.60(\mathrm{~m}, 4 \mathrm{H}), 7.43(\mathrm{~d}, J=6.7 \mathrm{~Hz}$, $2 \mathrm{H}), 7.08-7.23(\mathrm{~m}, 3 \mathrm{H}), 6.97(\mathrm{~d}, J=4.2 \mathrm{~Hz}, 1 \mathrm{H}), 5.17(\mathrm{~d}, J=12.2 \mathrm{~Hz}$, $1 \mathrm{H}), 4.31$ (t, $J=6.7 \mathrm{~Hz}, 1 \mathrm{H}), 4.04-4.15(\mathrm{~m}, 4 \mathrm{H}), 2.50$ (t, $J=13.3 \mathrm{~Hz}$, $1 \mathrm{H}), 2.34(\mathrm{t}, J=7.4 \mathrm{~Hz}, 1 \mathrm{H}), 1.73(\mathrm{dd}, J=13.2,9.3 \mathrm{~Hz}, 3 \mathrm{H}), 1.44(\mathrm{dd}$, $J=15.4,7.6 \mathrm{~Hz}, 3 \mathrm{H}), 0.88-0.93(\mathrm{~m}, 6 \mathrm{H})$.

${ }^{13} \mathrm{C}$ NMR $\left(101 \mathrm{MHz}, \mathrm{CDCl}_{3}\right): \delta=168.65,133.52,129.68,129.47$, $128.85,128.26,125.45,122.68,115.62,97.48,65.58,61.97,50.16$ (d, $J=36.2 \mathrm{~Hz}), 37.45,29.71,25.44,23.59,22.70,21.11,16.48,14.13$, 13.74 .

${ }^{31} \mathrm{P} \operatorname{NMR}\left(162 \mathrm{MHz}, \mathrm{CDCl}_{3}\right): \delta=26.80$.

HRMS (ESI): $m / z[\mathrm{M}+\mathrm{H}]^{+}$calcd for $\mathrm{C}_{26} \mathrm{H}_{30} \mathrm{NO}_{5} \mathrm{P}: 468.1895$; found: 468.1924.

\section{Diethyl(1-(phenylcycloprop-2-enyl)-2-(1,3-dioxoisoindolin-2- yl)propyl)phosphonate (3d)}

Yield: $0.079 \mathrm{~g}(60 \%) ;$ pale-yellow oil.

${ }^{1} \mathrm{H}$ NMR $\left(400 \mathrm{MHz}, \mathrm{CDCl}_{3}\right): \delta=7.54-7.64(\mathrm{~m}, 4 \mathrm{H}), 7.47(\mathrm{~d}, J=6.7 \mathrm{~Hz}$, $2 \mathrm{H}), 7.15-7.24(\mathrm{~m}, 3 \mathrm{H}), 6.99(\mathrm{~d}, J=4.2 \mathrm{~Hz}, 1 \mathrm{H}), 4.92-5.03(\mathrm{~m}, 1 \mathrm{H})$, 4.10 (ddd, $J=14.5,11.7,7.1 \mathrm{~Hz}, 4 \mathrm{H}), 2.35-2.42(\mathrm{~m}, 1 \mathrm{H}), 2.06-2.14$ (m, $1 \mathrm{H}), 1.34-1.49(\mathrm{~m}, 3 \mathrm{H}), 0.87(\mathrm{dd}, J=15.3,7.9 \mathrm{~Hz}, 6 \mathrm{H})$.

${ }^{13} \mathrm{C}$ NMR $\left(101 \mathrm{MHz}, \mathrm{CDCl}_{3}\right): \delta=168.66,133.56,131.39,129.72$, $129.52,128.29,125.55,122.71,115.64,97.64,61.97,53.99$ (d, $J=36.1 \mathrm{~Hz}), 22.71,22.11,14.14,11.20$.

${ }^{31} \mathrm{P}$ NMR $\left(162 \mathrm{MHz}, \mathrm{CDCl}_{3}\right): \delta=26.94$.

HRMS (ESI): $m / z[\mathrm{M}+\mathrm{H}]^{+}$calcd for $\mathrm{C}_{24} \mathrm{H}_{26} \mathrm{NO}_{5} \mathrm{P}: 440.1582$; found: 440.1619 .

(2-(Diethoxyphosphoryl)-1-(1,3-dioxoisoindolin-2-yl)-2-(phenylcycloprop-2-enyl)ethyl)phenyl Acetate (3e)

Yield: $0.087 \mathrm{~g}$ (54\%); pale-yellow oil.

${ }^{1} \mathrm{H}$ NMR (400 MHz, $\left.\mathrm{CDCl}_{3}\right): \delta=7.42-7.49(\mathrm{~m}, 5 \mathrm{H}), 7.14-7.21(\mathrm{~m}, 4 \mathrm{H})$, 6.96-7.11 (m, $2 \mathrm{H}), 6.82-6.86(\mathrm{~m}, 2 \mathrm{H}), 5.35-5.42(\mathrm{~m}, 1 \mathrm{H}), 4.13(\mathrm{dt}$, $J=7.1,4.7 \mathrm{~Hz}, 4 \mathrm{H}), 3.07-3.94(\mathrm{~m}, 1 \mathrm{H}), 3.69(\mathrm{dd}, J=14.2,12.6 \mathrm{~Hz}$, $1 \mathrm{H}), 3.47$ (dd, $J=14.4,4.2 \mathrm{~Hz}, 1 \mathrm{H}), 2.20(\mathrm{~s}, 3 \mathrm{H}), 1.32$ (dd, $J=7.0$, $3.5 \mathrm{~Hz}, 6 \mathrm{H})$.

${ }^{13} \mathrm{C}$ NMR $\left(101 \mathrm{MHz}, \mathrm{CDCl}_{3}\right): \delta=169.37,149.05,135.95,133.67$, $133.50,130.69,129.75,129.64,128.95,128.33,125.27,122.68$, 121.36, 115.53, 97.54, 62.07, 53.44 (d, $J=36.9 \mathrm{~Hz}), 34.38,29.72$, 21.10, 16.54 .

${ }^{31} \mathrm{P} \operatorname{NMR}\left(162 \mathrm{MHz}, \mathrm{CDCl}_{3}\right): \delta=26.52$.

HRMS (ESI): $m / z[\mathrm{M}+\mathrm{H}]^{+}$calcd for $\mathrm{C}_{31} \mathrm{H}_{30} \mathrm{NO}_{7} \mathrm{P}$ : 560.1793 ; found: 560.1838 .

Diethyl(1-(2-m-tolylcycloprop-2-enyl)-2-(1,3-dioxoisoindolin-2yl)-2-phenylethyl)phosphonate (3g)

Yield: $0.095 \mathrm{~g}(62 \%)$; pale-yellow oil.
${ }^{1} \mathrm{H}$ NMR $\left(400 \mathrm{MHz}, \mathrm{CDCl}_{3}\right): \delta=7.47(\mathrm{~s}, 4 \mathrm{H}), 7.24(\mathrm{~s}, 2 \mathrm{H}), 7.11-7.20$ (m, $4 \mathrm{H}), 7.02-7.09(\mathrm{~m}, 3 \mathrm{H}), 6.94(\mathrm{~d}, J=7.7 \mathrm{~Hz}, 1 \mathrm{H}), 5.35-5.45(\mathrm{~m}$, $1 \mathrm{H}), 4.09-4.19(\mathrm{~m}, 4 \mathrm{H}), 3.61-3.70(\mathrm{~m}, 1 \mathrm{H}), 3.47$ (dd, $J=14.2,4.2 \mathrm{~Hz}$, $1 \mathrm{H}), 2.18(\mathrm{~s}, 3 \mathrm{H}), 1.33$ (td, $J=7.0,3.5 \mathrm{~Hz}, 6 \mathrm{H})$.

${ }^{13} \mathrm{C}$ NMR $\left(101 \mathrm{MHz}, \mathrm{CDCl}_{3}\right): \delta=138.36,137.91,133.38,130.41$, $130.35,128.70,128.32,128.26,126.90,126.23,125.20,123.70$, 122.55, 115.48, 97.31, 62.03, $53.54(\mathrm{~d}, J=37.3 \mathrm{~Hz}), 34.96,29.71$, $21.05,16.52$.

${ }^{31} \mathrm{P}$ NMR $\left(162 \mathrm{MHz}, \mathrm{CDCl}_{3}\right): \delta=26.79$.

HRMS (ESI): $m / z[\mathrm{M}+\mathrm{H}]^{+}$calcd for $\mathrm{C}_{30} \mathrm{H}_{30} \mathrm{NO}_{5} \mathrm{P}: 516.1895$; found: 516.1912.

Dibutyl(1-(2-p-tolylcycloprop-2-enyl)-2-(1,3-dioxoisoindolin-2yl)-2-phenylethyl)phosphonate (3h)

Yield: $0.108 \mathrm{~g}$ (64\%); pale-yellow oil.

${ }^{1} \mathrm{H}$ NMR (400 MHz, $\mathrm{CDCl}_{3}$ ): $\delta=7.49$ (s, $\left.4 \mathrm{H}\right), 7.13-7.27$ (m, $5 \mathrm{H}$ ), 7.07 $(\mathrm{dt}, J=10.2,5.8 \mathrm{~Hz}, 3 \mathrm{H}), 6.96(\mathrm{~d}, J=7.4 \mathrm{~Hz}, 1 \mathrm{H}), 5.43(\mathrm{~d}, J=12.3 \mathrm{~Hz}$, $1 \mathrm{H}), 4.00-4.18(\mathrm{~m}, 4 \mathrm{H}), 3.64-3.74(\mathrm{~m}, 1 \mathrm{H}), 3.51(\mathrm{dd}, J=14.3,4.1 \mathrm{~Hz}$, $1 \mathrm{H}), 2.37(\mathrm{t}, J=7.4 \mathrm{~Hz}, 1 \mathrm{H}), 2.21(\mathrm{~s}, 3 \mathrm{H}), 1.35-1.52(\mathrm{~m}, 8 \mathrm{H}), 0.94(\mathrm{t}$, $J=7.2 \mathrm{~Hz}, 6 \mathrm{H})$.

${ }^{13} \mathrm{C}$ NMR $\left(101 \mathrm{MHz}, \mathrm{CDCl}_{3}\right): \delta=171.20,138.37,137.87,133.36$, $130.93,130.36,128.85,128.68,128.31,128.21,126.90,126.21$, $122.54,97.22,65.80,60.42,53.53(\mathrm{~d}, J=37.2 \mathrm{~Hz}), 34.97,32.66,31.93$, 29.70, 22.70, 21.07, 18.79, 14.20, 13.65 .

$\left.{ }^{31} \mathrm{P} \mathrm{NMR} \mathrm{(162} \mathrm{MHz,} \mathrm{CDCl}_{3}\right): \delta=26.74$.

HRMS (ESI): $m / z[\mathrm{M}+\mathrm{H}]^{+}$calcd for $\mathrm{C}_{34} \mathrm{H}_{38} \mathrm{NO}_{5} \mathrm{P}: 572.2521$; found: 572.2569 .

Diethyl(1-(4-fluorophenylcycloprop-2-enyl)-2-(1,3-dioxoisoindolin-2-yl)ethyl)phosphonate (3i)

Yield: $0.019 \mathrm{~g}(19 \%) ;$ pale-yellow oil.

${ }^{1} \mathrm{H}$ NMR (400 MHz, $\mathrm{CDCl}_{3}$ ): $\delta=7.50-7.56(\mathrm{~m}, 4 \mathrm{H}), 7.41$ (dd, $J, 7.41$ (dd Hz, $2 \mathrm{H}$ ), 6.82-6.89 (m, $3 \mathrm{H}$ ), 5.11 (d, J = 7.1 Hz, $1 \mathrm{H}$ ), 3.97-4.05 $(\mathrm{m}, 4 \mathrm{H}), 1.60(\mathrm{~d}, J, 1.6 \mathrm{~Hz}, 3 \mathrm{H}), 1.18-1.24(\mathrm{~m}, 6 \mathrm{H})$.

${ }^{13} \mathrm{C}$ NMR $\left(101 \mathrm{MHz}, \mathrm{CDCl}_{3}\right): \delta=168.30,133.67,131.86,131.78$, $131.51,122.74,115.57$ (d, $J 168.30 \mathrm{~Hz}$ ), 97.17, 61.96 (dd, $J=18.1$, $6.9 \mathrm{~Hz}), 47.39$ (d, J z), $47 \mathrm{~Hz}), 30.20,28.23,16.42$.

${ }^{31} \mathrm{P}$ NMR $\left(162 \mathrm{MHz}, \mathrm{CDCl}_{3}\right): \delta=26.56$.

HRMS (ESI): $m / z[\mathrm{M}+\mathrm{H}]^{+}$calcd for $\mathrm{C}_{23} \mathrm{H}_{24} \mathrm{FNO}_{5} \mathrm{P}: 444.1371$; found: 444.1378.

Diethyl(1-(4-methoxyphenylcycloprop-2-enyl)-2-(1,3-dioxoisoindolin-2-yl)-2-phenylethyl)phosphonate (3j)

Yield: $0.030 \mathrm{~g}(25 \%)$; pale-yellow oil.

${ }^{1} \mathrm{H}$ NMR (400 MHz, $\left.\mathrm{CDCl}_{3}\right): \delta=7.40-7.48(\mathrm{~m}, 5 \mathrm{H}), 7.13-7.19(\mathrm{~m}, 4 \mathrm{H})$, 7.09-7.10 (m, $1 \mathrm{H}) \quad 7.05(\mathrm{t}, J(\mathrm{t}, \mathrm{Hz}, 1 \mathrm{H}), 6.89(\mathrm{~d}, J(\mathrm{~d}, \mathrm{~Hz}, 1 \mathrm{H}), 6.71-$ 6.79 (m, $2 \mathrm{H}$ ), 5.38 (d, J (d, ( Hz, $1 \mathrm{H}), 4.12$ (dd, J(dd, $(400 \mathrm{M} \mathrm{Hz}, 4 \mathrm{H})$, $3.72(\mathrm{~s}, 3 \mathrm{H}), 3.62-3.69(\mathrm{~m}, 1 \mathrm{H}), 3.44-3.53(\mathrm{~m}, 1 \mathrm{H}), 1.29-1.34(\mathrm{~m}$, $6 \mathrm{H})$.

${ }^{13} \mathrm{C}$ NMR $\left(101 \mathrm{MHz}, \mathrm{CDCl}_{3}\right): \delta=160.63,138.46,133.38,131.44$, 128.70, 128.29, 126.19, 122.61, 118.09, 115.03, 113.88, 94.80, 61.97, 55.23, 53.68 (d, J J60.63 Hz), 34.99, 29.39, 27.40, 16.52, 16.45.

${ }^{31} \mathrm{P}$ NMR (162 MHz, $\left.\mathrm{CDCl}_{3}\right): \delta=26.93$.

HRMS (ESI): $m / z[\mathrm{M}+\mathrm{H}]^{+}$calcd for $\mathrm{C}_{30} \mathrm{H}_{31} \mathrm{NO}_{6} \mathrm{P}: 532.1884$; found: 532.1882 . 
Diethyl(1-(2-methyl-3-phenylcycloprop-2-enyl)-2-(1,3-dioxoisoindolin-2-yl)ethyl)phosphonate (3k)

Yield: $0.011 \mathrm{~g}(11 \%)$; pale-yellow oil.

${ }^{1} \mathrm{H} \mathrm{NMR}\left(400 \mathrm{MHz}, \mathrm{CDCl}_{3}\right): \delta=7.85-7.87(\mathrm{~m}, 2 \mathrm{H}), 7.72-7.74(\mathrm{~m}, 2 \mathrm{H})$, 7.58-7.60 (m, $1 \mathrm{H}), 7.52-7.54(\mathrm{~m}, 1 \mathrm{H}), 7.36(\mathrm{~d}, J \mathrm{~J} 7.3 \mathrm{~Hz}, 1 \mathrm{H}), 7.05-$ $7.16(\mathrm{~m}, 2 \mathrm{H}), 4.98-5.20(\mathrm{~m}, 1 \mathrm{H}), 4.05-4.15(\mathrm{~m}, 4 \mathrm{H}), 2.05(\mathrm{~s}, 3 \mathrm{H})$, 1.70 (dd, $J, 1.70$ (dd, Hz, 3 H), 1.24-1.29 (m, 6 H).

${ }^{13} \mathrm{C}$ NMR $\left(101 \mathrm{MHz}, \mathrm{CDCl}_{3}\right): \delta=167.37,134.11,133.43,131.67$, $129.14,128.25,128.15,123.49,122.63,108.45,108.0561 .41,47.60$ (d, J J47.60 Hz), 29.69, 21.03, 16.58, 15.16, 14.19.

${ }^{31} \mathrm{P}$ NMR $\left(162 \mathrm{MHz}, \mathrm{CDCl}_{3}\right): \delta=27.73$.

HRMS (ESI): $m / z[\mathrm{M}+\mathrm{H}]^{+}$calcd for $\mathrm{C}_{24} \mathrm{H}_{26} \mathrm{NO}_{5} \mathrm{P}: 440.1621$; found: 440.1613.

Dimethyl(1-(phenylcycloprop-2-enyl)-2-(1,3-dioxoisoindolin-2yl)ethyl)phosphonate (31)

Yield: $0.066 \mathrm{~g}$ (55\%); pale-yellow oil.

${ }^{1} \mathrm{H} \mathrm{NMR}\left(400 \mathrm{MHz}, \mathrm{CDCl}_{3}\right): \delta=7.54-7.65(\mathrm{~m}, 4 \mathrm{H}), 7.48(\mathrm{~d}, J=6.7 \mathrm{~Hz}$, $2 \mathrm{H}), 7.17-7.26(\mathrm{~m}, 3 \mathrm{H}), 7.03(\mathrm{~d}, J=4.2 \mathrm{~Hz}, 1 \mathrm{H}), 5.16-5.25(\mathrm{~m}, 1 \mathrm{H})$, $3.77(\mathrm{dd}, J=10.6,5.5 \mathrm{~Hz}, 6 \mathrm{H}), 1.72(\mathrm{~d}, J=7.2 \mathrm{~Hz}, 3 \mathrm{H})$.

${ }^{13} \mathrm{C}$ NMR $\left(101 \mathrm{MHz}, \mathrm{CDCl}_{3}\right): \delta=168.34,133.58,131.46,129.76$, $129.69,128.38,125.26,122.73,115.73,97.37,52.84,52.70,47.40$ (d, $J=37.1 \mathrm{~Hz}), 16.07$.

${ }^{31} \mathrm{P}$ NMR $\left(162 \mathrm{MHz}, \mathrm{CDCl}_{3}\right): \delta=29.30$.

HRMS (ESI): $m / z[\mathrm{M}+\mathrm{H}]^{+}$calcd for $\mathrm{C}_{21} \mathrm{H}_{20} \mathrm{NO}_{5} \mathrm{P}$ : 398.1113; found: 398.1148.

\section{Dimethyl(1-(phenyl-cycloprop-2-enyl)-2-(1,3-dioxoisoindolin-2-} yl)-2-phenyl-ethyl)phosphonate (3m)

Yield: $0.093 \mathrm{~g}(66 \%)$; pale-yellow oil.

${ }^{1} \mathrm{H} \mathrm{NMR}\left(400 \mathrm{MHz}, \mathrm{CDCl}_{3}\right): \delta=7.45-7.51(\mathrm{~m}, 5 \mathrm{H}), 7.13-7.24(\mathrm{~m}, 7 \mathrm{H})$, 7.08 (dd, $J=12.8,5.7 \mathrm{~Hz}, 2 \mathrm{H}), 5.39$ (ddd, $J=12.4,4.3,2.6 \mathrm{~Hz}, 1 \mathrm{H}$ ), 3.79-3.84(m, $6 \mathrm{H}), 3.61-3.74(\mathrm{~m}, 2 \mathrm{H}), 3.46-3.50(\mathrm{~m}, 1 \mathrm{H})$.

${ }^{13} \mathrm{C}$ NMR $\left(101 \mathrm{MHz}, \mathrm{CDCl}_{3}\right): \delta=138.16,133.49,129.76,129.73$, $129.63,128.70,128.42,128.35,126.29,125.10,123.48,122.66$, $115.33,97.46,53.44(\mathrm{~d}, J=37.0 \mathrm{~Hz}), 34.94$.

${ }^{31} \mathrm{P} \operatorname{NMR}\left(162 \mathrm{MHz}, \mathrm{CDCl}_{3}\right): \delta=29.11$.

HRMS (ESI): $m / z[\mathrm{M}+\mathrm{H}]^{+}$calcd for $\mathrm{C}_{27} \mathrm{H}_{24} \mathrm{NO}_{5} \mathrm{P}: 474.1426$; found: 474.1468.

Diisopropyl(1-(phenylcycloprop-2-enyl)-2-(1,3-dioxoisoindolin-2yl)-2-phenylethyl)phosphonate (3n)

Yield: $0.094 \mathrm{~g}(60 \%)$; pale-yellow oil.

${ }^{1} \mathrm{H}$ NMR $\left(400 \mathrm{MHz}, \mathrm{CDCl}_{3}\right.$ ): $\delta=7.70(\mathrm{dd}, J=26.3,19.1 \mathrm{~Hz}, 6 \mathrm{H}), 7.37-$ $7.51(\mathrm{~m}, 3 \mathrm{H}), 7.21(\mathrm{~d}, J=4.3 \mathrm{~Hz}, 1 \mathrm{H}), 7.00-7.09(\mathrm{~m}, 4 \mathrm{H}), 5.44(\mathrm{~d}$, $J=8.9 \mathrm{~Hz}, 1 \mathrm{H}), 4.52(\mathrm{ddd}, J=13.4,11.0,6.2 \mathrm{~Hz}, 2 \mathrm{H}), 2.74-3.25(\mathrm{~m}$, $2 \mathrm{H}$ ), 2.55 (dd, $J=14.0,4.2 \mathrm{~Hz}, 1 \mathrm{H}), 1.19$ (d, $J=6.2 \mathrm{~Hz}, 6 \mathrm{H}), 1.03$ (dd, $J=16.5,6.2 \mathrm{~Hz}, 6 \mathrm{H})$.

${ }^{13} \mathrm{C}$ NMR $\left(101 \mathrm{MHz}, \mathrm{CDCl}_{3}\right): \delta=153.59,140.51,137.65,133.50$, $129.97,128.85,128.09 .127 .98,127.57,126.44,126.29,123.42$, 116.36, 100.21, 70.03 (d, $J=7.4 \mathrm{~Hz}$ ), 52.71 (d, $J=25.3 \mathrm{~Hz}), 35.70$, 29.71, 23.78 .

${ }^{31} \mathrm{P} \operatorname{NMR}\left(162 \mathrm{MHz}, \mathrm{CDCl}_{3}\right): \delta=24.92$.

HRMS (ESI): $m / z[\mathrm{M}+\mathrm{H}]^{+}$calcd for $\mathrm{C}_{31} \mathrm{H}_{32} \mathrm{NO}_{5} \mathrm{P}: 530.2052$; found: 530.2091.
Dibutyl(1-(phenylcycloprop-2-enyl)-2-(1,3-dioxoisoindolin-2yl)ethyl)phosphonate (3o)

Yield: $0.096 \mathrm{~g}(67 \%)$; pale-yellow oil.

${ }^{1} \mathrm{H} \mathrm{NMR}\left(400 \mathrm{MHz}, \mathrm{CDCl}_{3}\right): \delta=7.57-7.62(\mathrm{~m}, 2 \mathrm{H}), 7.52-7.56(\mathrm{~m}, 2 \mathrm{H})$, $7.45(\mathrm{~d}, J=6.8 \mathrm{~Hz}, 2 \mathrm{H}), 7.14-7.23(\mathrm{~m}, 3 \mathrm{H}), 6.98(\mathrm{~d}, J=4.1 \mathrm{~Hz}, 1 \mathrm{H})$, $5.21(\mathrm{dt}, J=6.9,5.1 \mathrm{~Hz}, 1 \mathrm{H}), 3.98-4.05(\mathrm{~m}, 4 \mathrm{H}), 1.70(\mathrm{~d}, J=7.2 \mathrm{~Hz}$, $3 \mathrm{H}), 1.56-1.64(\mathrm{~m}, 4 \mathrm{H}), 1.36$ (dd, $J=7.3,4.6 \mathrm{~Hz}, 4 \mathrm{H}), 0.87-0.92(\mathrm{~m}$, $6 \mathrm{H})$.

${ }^{13} \mathrm{C}$ NMR $\left(101 \mathrm{MHz}, \mathrm{CDCl}_{3}\right): \delta=168.30,133.51,131.50,129.76$, $129.52,128.23,125.49,122.67,116.09,97.56,65.58,47.49$ (d, $J=36.9 \mathrm{~Hz}), 32.70,32.41,18.71,16.17,13.58$.

${ }^{31} \mathrm{P}$ NMR (162 MHz, $\left.\mathrm{CDCl}_{3}\right): \delta=26.73$.

HRMS (ESI): $m / z[\mathrm{M}+\mathrm{H}]^{+}$calcd for $\mathrm{C}_{27} \mathrm{H}_{32} \mathrm{NO}_{5} \mathrm{P}: 482.2052$; found: 482.2094 .

Dibutyl(1-(phenylcycloprop-2-enyl)-2-(1,3-dioxoisoindolin-2-yl)2-phenylethyl)phosphonate (3p)

Yield: $0.099 \mathrm{~g}(60 \%)$; pale-yellow oil.

${ }^{1} \mathrm{H}$ NMR (400 MHz, $\left.\mathrm{CDCl}_{3}\right): \delta=7.45(\mathrm{~d}, J=8.2 \mathrm{~Hz}, 5 \mathrm{H}), 7.11-7.21(\mathrm{~m}$, $7 \mathrm{H}), 7.05(\mathrm{~d}, J=4.0 \mathrm{~Hz}, 2 \mathrm{H}), 5.36-5.46(\mathrm{~m}, 1 \mathrm{H}), 4.07(\mathrm{tt}, J=13.4$, $6.7 \mathrm{~Hz}, 4 \mathrm{H}$ ), 3.80 (ddd, $J=31.7,18.3,9.8 \mathrm{~Hz}, 2 \mathrm{H}$ ), 3.50 (dd, $J=14.3$, $4.1 \mathrm{~Hz}, 1 \mathrm{H}), 1.61-1.68(\mathrm{~m}, 4 \mathrm{H}), 1.39(\mathrm{dd}, J=11.2,4.0 \mathrm{~Hz}, 4 \mathrm{H}), 0.91$ (td, $J=7.3,1.4 \mathrm{~Hz}, 6 \mathrm{H}$ ).

${ }^{13} \mathrm{C}$ NMR $\left(101 \mathrm{MHz}, \mathrm{CDCl}_{3}\right): \delta=138.38,133.43,129.75,129.59$, $128.68,128.33,128.30,126.23,125.36,123.68,122.62,115.62,97.59$, $65.74,53.60(\mathrm{~d}, J=37.3 \mathrm{~Hz}), 35.02,32.66,29.68,18.78,13.66$.

${ }^{31} \mathrm{P}$ NMR (162 MHz, $\left.\mathrm{CDCl}_{3}\right): \delta=26.53$.

HRMS (ESI): $m / z[\mathrm{M}+\mathrm{H}]^{+}$calcd for $\mathrm{C}_{33} \mathrm{H}_{36} \mathrm{NO}_{5} \mathrm{P}: 558.2365$; found: 558.2412 .

\section{(Z)-Diethyl(2-(1,3-dioxoisoindolin-2-yl)prop-1-en-1-yl)phospho-} nate (4a)

Yield: $0.014 \mathrm{~g}$ (15\%); white solid; mp $140-143^{\circ} \mathrm{C}$.

${ }^{1} \mathrm{H}$ NMR $\left(400 \mathrm{MHz}, \mathrm{CDCl}_{3}\right): \delta=7.87-7.94(\mathrm{~m}, 2 \mathrm{H}, \mathrm{Ph}), 7.69-7.80(\mathrm{~m}$, $2 \mathrm{H}, \mathrm{Ph}), 5.96$ (dd, $J=10.4,1.2 \mathrm{~Hz}, 1 \mathrm{H}, \mathrm{CH}), 3.98-4.13\left(\mathrm{~m}, 4 \mathrm{H}, 2{ }^{\circ} \mathrm{CH}_{2}\right)$, $2.25\left(\mathrm{~s}, 3 \mathrm{H}, \mathrm{CH}_{3}\right), 1.28\left(\mathrm{t}, J=7.1 \mathrm{~Hz}, 6 \mathrm{H}, 2 \mathrm{CH}_{3}\right)$.

${ }^{13} \mathrm{C}$ NMR (101 MHz, $\left.\mathrm{CDCl}_{3}\right): \delta=166.63(\mathrm{C}=0), 146.83(\mathrm{CN}), 134.11$, 132.28, $123.71(\mathrm{Ph}), 118.32(\mathrm{~d}, J=186.2 \mathrm{~Hz}, \mathrm{CP}), 62.08(\mathrm{~d}, J=5.3 \mathrm{~Hz}$, $\left.\mathrm{OCH}_{2}\right), 24.56\left(\mathrm{~d}, J=17 \mathrm{~Hz}, \mathrm{CH}_{3}\right), 16.27\left(\mathrm{~d}, J=6.6 \mathrm{~Hz}, \mathrm{CH}_{3}\right)$.

${ }^{31} \mathrm{P} \operatorname{NMR}\left(162 \mathrm{MHz}, \mathrm{CDCl}_{3}\right): \delta=11.34(\mathrm{~s})$.

HRMS (ESI): $m / z$ [M + Na] ${ }^{+}$calcd for $\mathrm{C}_{15} \mathrm{H}_{18} \mathrm{NO}_{5} \mathrm{PNa}$ : 346.0815; found: 346.0815 .

\section{Funding Information}

We thank the Committee of Science and Technology of Tianjin (15JCYBJC20700), the Tianjin Rural Work Committee (201604020) and State Key Laboratory of Elemento-Organic Chemistry in Nankai University for financial support.

\section{Supporting Information}

Supporting information for this article is available online at https://doi.org/10.1055/s-0036-1590969. 


\section{References}

(1) (a) Rubin, M.; Rubina, M.; Gevorgyan, V. Chem. Rev. 2007, 107, 3117. (b) Rubin, M.; Rubina, M.; Gevorgyan, V. Synthesis 2006, 1221. (c) Fox, J. M.; Yan, N. Curr. Org. Chem. 2005, 9, 719. (d) Nakamura, M.; Isobe, H.; Nakamura, E. Chem. Rev. 2003, 103, 1295. (e) Song, C. L.; Wang, J. W.; Xu, Z. H. Acta Chim. Sin. 2015, 73, 1114. (f) Prosser, A. R.; Banning, J. E.; Rubina, M.; Rubin, M. Org. Lett. 2010, 12, 3968. (g) Banning, J. E.; Prosser, A. R.; Rubin, M. Org. Lett. 2010, 12, 1488. (h) Alnasleh, B. K.; Sherrill, W. M.; Rubina, M.; Banning, J.; Rubin, M. J. Am. Chem. Soc. 2009, 131, 6906. (i) Sherrill, W. M.; Rubin, M. J. Am. Chem. Soc. 2008, 130, 13804. (j) Alnasleh, B. K.; Sherrill, W. M.; Rubin, M. Org. Lett. 2008, 10, 3231. (k) Xie, X. C.; Yang, Z.; Fox, J. M. J. Org. Chem. 2010, 75, 3847. (l) Tarwade, V.; Liu, X. Z.; Yan, N.; Fox, J. M. J. Am. Chem. Soc. 2009, 131, 5382. (m) Yan, N.; Liu, X. Z.; Fox, J. M. J. Org. Chem. 2008, 73, 563. (n) Fisher, L. A.; Fox, J. M. J. Org. Chem. 2008, 73, 8474. (o) Simaan, M.; Delaye, P. O.; Shi, M. Angew. Chem. Int. Ed. 2015, 54, 12345. (p) Song, C. L.; Wang, J. W.; Xu, Z. H. Org. Biomol. Chem. 2014, 12, 5802. (q) Wallbaum, J.; Jones, P. G.; Werz, D. B. J. Org. Chem. 2015, 80, 3730. (r) Tian, Z. X.; Lis, L.; Kass, S. R. J. Org. Chem. 2013, 78, 12650.

(2) (a) Simaan, S.; Masarwa, A.; Zohar, E.; Stanger, A.; Bertus, P.; Marek, I. Chem. Eur. J. 2009, 15, 8449. (b) Hoveyda, A. H.; Lombardi, P. J.; O'Brien, R. V.; Zhugralin, A. R. J. Am. Chem. Soc. 2009, 131, 8378. (c) Marek, I.; Simaan, S.; Masarwa, A. Angew. Chem. Int. Ed. 2007, 46, 7364. (d) Sherill, W. M.; Rubin, M. J. Am. Chem. Soc. 2008, 130, 13804. (e) Tarwade, V.; Liu, X.; Yan, N.; Fox, J. M. J. Am. Chem. Soc. 2009, 131, 5382. (f) Briones, J. F.; Davies, H. M. L. J. Am. Chem. Soc. 2012, 134, 11916. (g) Zhu, Z. B.; Wei, Y.; Shi, M. Chem. Soc. Rev. 2011, 40, 5534. (h) Lindsay, V. N. G.; Fiest, D.; Gritsch, P. J.; Azzi, S.; Charette, A. B. J. Am. Chem. Soc. 2013, 135, 1463.

(3) (a) Perez, P. J.; Brookhart, M.; Templeton, J. L. Organometallics 1993, 12, 261. (b) Cho, D. J.; Jeon, S. J.; Kim, H. S.; Cho, C. S.; Shim, S. C.; Kim, T. J. Tetrahedron: Asymmetry 1999, 10, 3833. (c) Doyle, M. P.; Hu, W. H. Tetrahedron Lett. 2000, 41, 6265. (d) Doyle, M. P.; Hu, W. H. Synlett 2001, 9, 1364. (e) Swenson, A. K.; Higgins, K. E.; Brewer, M. G. Org. Biomol. Chem. 2012, 10, 7483. (f) Martin, C.; Sierra, M.; Alvarez, T.; Belderrain, T. R.; Perez, P. J. Dalton Trans. 2012, 5319. (g) Thomas, T. J.; Merritt, B. A.; Lemma, B. E. Org. Biomol. Chem. 2016, 14, 1742.

(4) Uehara, M.; Suematsu, H.; Yasutomi, Y.; Katsuki, T. J. Am. Chem. Soc. 2011, 133, 170.

(5) (a) Cui, X.; Xu, X.; Lu, H. J.; Zhu, S. F.; Woitas, L.; Zhang, X. P. J. Am. Chem. Soc. 2011, 133, 3304. (b) Cui, X.; Xu, X.; Woitas, L.; Kim, M. M.; Zhang, X. P. J. Am. Chem. Soc. 2012, 134, 19981.

(6) (a) Weatherhead-Kloster, R. A.; Corey, E. J. Org. Lett. 2006, 8, 171. (b) Chuprakov, S.; Gevorgyan, V. Org. Lett. 2007, 9, 4463. (c) Briones, J. F.; Hansen, J.; Hardcastle, K. I.; Autschbach, J.; Davies, H. M. L. J. Am. Chem. Soc. 2010, 132, 17211. (d) Panne, P.; Fox, J. M. J. Am. Chem. Soc. 2007, 129, 22. (e) Morandi, B.; Carreira, E. M. Angew. Chem. Int. Ed. 2010, 49, 4294. (f) Goto, T.; Takeda, K.; Shimada, N. Angew. Chem. Int. Ed. 2011, 50, 6803. (g) Briones, J. F.; Davies, H. M. L. Tetrahedron 2011, 67, 4313. (h) Xu, X. F.; Deng, Y. M.; Yim, D. N.; Zavalij, P. Y.; Doyle, M. P. Chem. Sci. 2015, 6, 2196. (i) Edwards, A.; Rubin, M. Tetrahedron 2015, 71, 3237.

(7) (a) Wu, C. G.; Liu, Z. X.; Zhang, Z. K.; Ye, F.; Deng, G. S.; Zhang, Y.; Wang, J. B. Adv. Synth. Catal. 2016, 358, 2480. (b) Zhou, Y. J.; Ye, F.; Zhou, Q.; Zhang, Y.; Wang, J. B. Org. Lett. 2016, 18, 2024.
(8) (a) Protopopova, M. N.; Doyle, M. P.; Müller, P.; Ene, D. J. Am. Chem. Soc. 1992, 114, 2755. (b) Doyle, M. P.; Protopopova, M.; Müller, P.; Ene, D.; Shapiro, E. A. J. Am. Chem. Soc. 1994, 116, 8492. (c) Doyle, M. P.; Ene, D.; Peterson, C. S.; Lynch, V. Angew. Chem. Int. Ed. 1999, 38, 700.

(9) Lou, Y.; Horikawa, M.; Kloster, R. A.; Hawryluk, N. A.; Corey, E. J. J. Am. Chem. Soc. 2004, 126, 8916.

(10) Davies, H. M. L.; Lee, G. H. Org. Lett. 2004, 6, 1233.

(11) Briones, J. F.; Davies, H. M. L. Org. Lett. 2011, 13, 3984.

(12) (a) Zhu, S. F.; Chen, W. Q.; Zhang, Q. Q.; Mao, H. X.; Zhou, Q. L. Synlett 2011, 7, 919. (b) Zhou, C. Y.; Wang, J. C.; Wei, J. H.; Xu, Z. J.; Guo, Z.; Low, K. H.; Che, C. M. Angew. Chem. Int. Ed. 2012, 51, 11376. (c) Lindsay, V. N. G.; Fiset, D.; Gritsch, P. J.; Azzi, S.; Charette, A. B. J. Am. Chem. Soc. 2013, 135, 1463. (d) Wang, J.; Boyarshikh, V.; Rainier, J. D. Org. Lett. 2011, 13, 700. (e) Davies, H. M. L.; Lee, G. H. Org. Lett. 2004, 6, 2117. (f) Zhang, H.; Wen, X. J.; Gan, L. H.; Peng, Y. G. Org. Lett. 2012, 14, 2126. (g) Hashimoto, T.; Maruoka, K. J. Am. Chem. Soc. 2007, 129, 10054. (h) Marmor, R. S.; Seyferth, D. J. Org. Chem. 1971, 36, 128.

(13) Lindsay, V. N. G.; Fiset, D.; Gritsch, P. J.; Azzi, S.; Charette, A. B. J. Am. Chem. Soc. 2013, 135, 1463.

(14) (a) Pyun, H. J.; Chaudhary, K.; Somoza, J. Z.; Sheng, X. C.; Kim, U. C. Tetrahedron Lett. 2009, 50, 3833. (b) Sheng, X. C.; Pyun, H.-J.; Chaudhary, K.; Wang, J.; Doerffler, E.; Fleury, M.; McMurtrie, D.; Chen, X.; Delaney, I. W. E.; Kim, C. U. Bioorg. Med. Chem. Lett. 2009, 19, 3453. (c) Clarke, M. O.; Chen, X.; Cho, A.; Delaney, I. W. E.; Doerffler, E.; Fardis, M.; Ji, M.; Mertzman, M.; Pakdaman, R.; Pyun, H.-J.; Rowe, T.; Yang, C. Y.; Sheng, X. C.; Kim, C. U. Bioorg. Med. Chem. Lett. 2011, 21, 3568. (d) Sheng, X. C.; Casarez, A.; Cai, R.; Clarke, M. O.; Chen, X.; Cho, A.; Delaney, I. W. E.; Doerffler, E.; Ji, M.; Mertzman, M.; Pakdaman, R.; Pyun, H.-J.; Rowe, T.; Wu, Q.; Xu, J.; Kim, C. U. Bioorg. Med. Chem. Lett. 2012, 22, 1394. (e) Gulevich, A. V.; Helan, V.; Wink, D. J.; Gevorgyan, V. Org. Lett. 2013, 15, 956.

(15) (a) Moore, J. D.; Sprott, K. T.; Wrobleski, A. D.; Hanson, P. R. Org. Lett. 2002, 4, 2357. (b) Moore, J. D.; Hanson, P. R. Tetrahedron: Asymmetry 2003, 14, 873. (c) Chemagin, A. V.; Yashin, N. V.; Grishin, Y. K.; Kuznetsova, T. S.; Zefirov, N. S. Synthesis 2010, 259. (d) Chemagin, A. V.; Yashin, N. V.; Grishin, Y. K.; Kuznetsova, T. S.; Zefirov, N. S. Synthesis 2010, 3379.

(16) Cai, Y.; Lu, Y. C.; Yu, C. B.; Lyu, H. R.; Miao, Z. W. Org. Biomol. Chem. 2013, 11, 5491.

(17) Cai, Y.; Ge, H. H.; Sun, W. Z.; Miao, Z. W. Synthesis 2015, 47, 1669.

(18) (a) Kong, S. S.; Fan, W. D.; Wu, G. P.; Miao, Z. W. Angew. Chem. Int. Ed. 2012, 51, 8864. (b) Fang, Z. J.; Yang, H. H.; Miao, Z. W.; Chen, R. Y. Helv. Chim. Acta 2011, 94, 1586. (c) Wang, Y. D.; Wang, Y. Y.; Yu, J. P.; Miao, Z. W.; Chen, R. Y. Chem. Eur. J. 2009, 15, 9290. (d) Wang, Y. D.; Wang, F.; Wang, Y. Y.; Miao, Z. W.; Chen, R. Y. Adv. Synth. Catal. 2008, 350, 2339. (e) Cai, Y.; Lyu, H. R.; Yu, C. B.; Miao, Z. W. Adv. Synth. Catal. 2014, 356, 596. (f) Cai, Y.; Ge, H. H.; Yu, C. B.; Sun, W. Z.; Zhan, J. C.; Miao, Z. W. RSC Adv. 2014, 4, 21492. (g) Ge, H. H.; Liu, S.; Cai, Y.; Sun, Y. C.; Miao, Z. W. Synthesis 2016, 48, 448.

(19) See the Supporting Information.

(20) (a) Zhu, S. F.; Xu, B.; Wang, G. P.; Zhou, Q. L. J. Am. Chem. Soc. 2012, 134, 436. (b) Jiang, J.; Xu, H. D.; Xi, J. B.; Ren, B. Y.; Lv, F. P.; Guo, X.; Jiang, L. Q.; Zhang, Z. Y.; Hu, W. H. J. Am. Chem. Soc. 2011, 133, 8428. 